\title{
The Syriac versions of Old Testament quotations in Matthew
}

\begin{tabular}{|c|c|}
\hline \multicolumn{2}{|c|}{$\begin{array}{l}\text { Author: } \\
\text { Herrie F. van Rooy }{ }^{1}\end{array}$} \\
\hline \multicolumn{2}{|c|}{$\begin{array}{l}\text { Affiliation: } \\
{ }^{1} \text { Faculty of Theology, } \\
\text { North-West University, } \\
\text { Potchefstroom Campus, } \\
\text { South Africa }\end{array}$} \\
\hline \multicolumn{2}{|c|}{$\begin{array}{l}\text { Correspondence to: } \\
\text { Herrie van Rooy }\end{array}$} \\
\hline \multicolumn{2}{|c|}{$\begin{array}{l}\text { Email: } \\
\text { herrie.vanrooy@nwu.ac.za }\end{array}$} \\
\hline \multicolumn{2}{|c|}{$\begin{array}{l}\text { Postal address: } \\
\text { Faculty of Theology, } \\
\text { North-West University, } \\
\text { Potcheftroom Campus, } \\
\text { Potchefstroom 2520, } \\
\text { South Africa }\end{array}$} \\
\hline \multicolumn{2}{|c|}{$\begin{array}{l}\text { Received: } 17 \text { Dec. } 2014 \\
\text { Accepted: } 21 \text { May } 2015 \\
\text { Published: } 18 \text { Dec. } 2015\end{array}$} \\
\hline \multicolumn{2}{|c|}{$\begin{array}{l}\text { How to cite this article: } \\
\text { Van Rooy, H.F., 2015, 'The } \\
\text { Syriac versions of Old } \\
\text { Testament quotations in } \\
\text { Matthew', In die Skriflig } \\
\text { 49(1), Art. \#1916, } 12 \text { pages. } \\
\text { http://dx.doi.org/10.4102/ } \\
\text { ids.v49i1.1916 }\end{array}$} \\
\hline \multicolumn{2}{|c|}{$\begin{array}{l}\text { Note: } \\
\text { This article deals with } \\
\text { the Syriac versions of Old } \\
\text { Testament quotations } \\
\text { introduced by a formula } \\
\text { containing the verb } \pi \lambda \eta \rho \text { õv } \\
\text { in the Gospel of Matthew. It is } \\
\text { an important contribution to } \\
\text { the study of these quotations, } \\
\text { as the Syriac versions of this } \\
\text { group of quotations have not } \\
\text { yet received detailed attention. } \\
\text { This work is based on the } \\
\text { research supported by } \\
\text { the National Research } \\
\text { Foundation. Any opinion, } \\
\text { finding and conclusion or } \\
\text { recommendation expressed } \\
\text { in this material is that of } \\
\text { the author and the National } \\
\text { Research Foundation does } \\
\text { not accept any liability in this } \\
\text { regard. }\end{array}$} \\
\hline \multicolumn{2}{|l|}{ Read online: } \\
\hline 品舟品 & $\begin{array}{l}\text { Scan this } Q R \\
\text { code with your } \\
\text { smart phone or } \\
\text { mobile device } \\
\text { to read online. }\end{array}$ \\
\hline
\end{tabular}

In the Gospel of Matthew 10 quotations from the Old Testament are introduced by a formula containing the verb $\pi \lambda \eta \rho \circ \tilde{v}$. This article explores the rendering of 9 of these 10 quotations in 3 Syriac versions of the New Testament, namely the Peshitta and the 2 versions of the Old Syriac Gospels (Sinaiticus and Curetonianus). The question addressed is the relationship of the Syriac versions to one another, to the Peshitta of the Old Testament and to the Greek Gospel. For the quotations in Matthew, their relationship to the Hebrew and Greek Old Testament is very important. In the quotations discussed, the Greek New Testament did not make much use of the Septuagint as it is known today. The Old Testament Peshitta influenced the Old Syriac, but not to the same extent in all instances. This influence could have been through Tatian's Diatessaron. Tatian probably used the text of the Old Testament Peshitta for the quotations of the Old Testament in the gospels. In instances where the Curetonianus and the Sinaiticus differ, it could demonstrate attempts to bring the text closer to the Greek New Testament. The New Testament Peshitta normally started with a text close to the Old Syriac, but frequently adapted it to bring it closer to New Testament Greek.

Die Siriese weergawes van die Ou-Testamentiese aanhalings in Matteus. Die Evangelie van Matteus het 10 aanhalings uit die Ou Testament wat deur ' $n$ formule met die werkwoord, $\pi \lambda \eta \rho 0 \tilde{v}$, ingelei word. Hierdie artikel ondersoek die weergawe van 9 van die 10 aanhalings in drie Siriese weergawes van die Nuwe Testament, naamlik die Peshitta en die twee weergawes van die Ou Siriese Evangelies (Sinaiticus en Curetonianus). Die vraagstuk handel oor die verhouding van die drie Siriese weergawes tot mekaar, tot die Peshitta van die Ou Testament en die Griekse Evangelie. Vir die aanhalings in Matteus is hulle verhouding tot die Hebreeuse en Griekse Ou Testament baie belangrik. In die aanhalings wat bespreek word, maak die Griekse Nuwe Testament nie veel van die Septuagint gebruik soos dit vandag bekend is nie. Die Ou Testament Peshitta het die Oud Siriese Evangelies beïnvloed, maar nie tot dieselfde mate in al die voorbeelde nie. Hierdie invloed kon geskied het via Tatianus se Diatessaron. Tatianus het waarskynlik die teks van die Peshitta van die Ou Testament vir die Ou-Testamentiese aanhalings in die Evangelies gebruik. In die gevalle waar die Curetonianus en die Sinaiticus verskil, is die verskille waarskynlik te wyte aan pogings om die teks nader aan die Griekse Nuwe Testament te bring. Die Nuwe Testament Peshitta het waarskynlik met ' $n$ teks naby aan die Oud Siriese begin, maar het dit dikwels aangepas om dit nader aan die Griekse Nuwe Testament te bring.

\section{Introduction}

In the Gospel of Matthew 10 quotations from the Old Testament are introduced by a formula containing the verb $\pi \lambda \eta \rho \circ \tilde{v}$. This article will explore the rendering of these 10 quotations in 3 Syriac versions of the New Testament, namely the Peshitta and the 2 versions of the Old Syriac Gospels (Sinaiticus and Curetonianus). The question addressed is the relationship of the Syriac versions to the Peshitta of the Old Testament and the Greek Gospel. In the case of the Greek Gospel its relationship to the Hebrew and the Septuagint is also relevant. Matters that are important for this issue are word order, the choice of lexical items and the verbal forms employed. Not all examples will be presented in great detail. Matthew 2:23 will not be discussed, as the Old Testament reference is very brief, which makes it difficult to determine the exact passage to which it refers. The nine instances discussed below do not have parallels in the other Gospels, making them very suitable for such an investigation.

\section{Background pertaining to the different texts}

This article deals with biblical texts in Hebrew, Greek and Syriac, with the aim to trace the background of passages quoted from the Old Testament in the Old Syriac and Peshitta versions 
of Matthew. The form of the quotations in the Greek Matthew is related to the question of the sources used by Matthew for these quotations. The quotations could have been taken from an Old Testament text, but they could also have been abbreviated or adapted for the purpose of the evangelist. He could have used the quotations from a Hebrew text of the Old Testament or from the Greek (Septuagint). The 10 quotations under consideration come from Isaiah, Jeremiah, Hosea, Zechariah and Psalms. Most of them are from Isaiah. The Hebrew text of the Old Testament had not been standardised at the time of the New Testament, so that one has to consider a different Vorlage when the quotation differs from the Hebrew text. In many instances, quotations from the Old Testament in the New Testament agree with the Septuagint in cases where the Septuagint differs from the Masoretic text (which postdates the time of the New Testament). The Septuagint has its own history of translation and transmission, but the quotations in the New Testament should be considered prehexaplaric. One has to evaluate the text in the New Testament against this background of the history of the transmission of the Septuagint.

As far as the form of the quotations in the Syriac texts is concerned, the history of the different Syriac versions must also be taken into account. In this regard, the article by Brock (1992) gives a good summary of the relevant information. The Peshitta of the Old Testament was mainly translated in the first 2 centuries AD (1992:794). As the Syro-Hexapla is much younger than the New Testament Syriac versions discussed in this article, it can be ignored in this discussion. As far as the New Testament is concerned, the Diatessaron is the earliest translation into Syriac, dating from the 2nd century (1992:796). The Diatessaron was probably compiled in Syriac from the beginning (Joosten 2001:502). The first translation of the four individual Gospels is the Old Syriac translation from the 3rd century AD (cf. Brock 1992:796). Of the Old Syriac, there are two manuscripts of the Gospels, Curetonianus and Sinaiticus. They differ from one another, in some instances quite substantially. ${ }^{1}$ Sinaiticus (Codex Syriacus 30 from St. Catherine's Monastery; Kiraz 1996) can be regarded as the best copy and the manuscript is a palimpsest, with the Gospel text dating from the late fourth or early 5th century. Curetonianus (British Library Add 14451; Kiraz 1996) was partly published by W. Cureton in 1858. The Peshitta of the New Testament is not a new translation, but a revision of the Old Syriac (or the Diatessaron) to bring it closer to the Greek. It probably dates from the early 5th century and the revision could have been done using an early Byzantine text of the New Testament in Greek (Brock 1992:796-797). The line of development of the Old Testament quotations started at the Hebrew Old Testament, then the Septuagint in some instances, the Greek New Testament, the Peshitta of the Old Testament (that could have been used in some instances by the New Testament in Syriac), the Diatessaron, the Old Syriac Gospels and finaly the Peshitta of the New Testament. This line of development must be kept in mind when studying the
Old Testament quotations in the Syriac versions of the New Testament. However, it must not be regarded as a unilinear development.

An important question in this regard is to what extent did the translators of the Old Syriac Gospels and the New Testament Peshitta make use of Tatian's version of the quotations. Joosten (1990:55) points out that it has been known for quite some time that the quotations in the Old Syriac and the New Testament Peshitta are not a translation from the Greek Gospels, but rather originate in the Old Testament Peshitta. Brock (1977:96-98) was the first one who indicated this. In his study of all the Old Testament quotations in the gospels, Joosten (1990:58-59) summarised his findings in three points:

- Tatian consistently used the Old Testament Peshitta for the quotations, even in instances where the Old Testament Peshitta differs from the Greek.

- The Old Syriac Gospels and the New Testament Peshitta independently used the Diatessaron, including the Old Testament Peshitta versions of the quotations.

- The Syriac Gospels demonstrate an attempt to correct the Old Testament quotations on the basis of the Greek New Testament. This happens more in the New Testament Peshitta than in the Old Syriac Gospels.

Joosten does not discuss all the Old Testament quotations in the four Gospels, but gave special attention to those instances where the influence of the Old Testament Peshitta can be discerned.

In a later work, Joosten (1996) discusses the quotations again. He states that the two Old Syriac Gospels agree in most instances. Differences between them may be ascribed to corruption or correction in one or both of them (1996:7-10). They depend on a common Old Syriac text. He thinks that the original Old Syriac translator made use of the Diatessaron and tried to retain as much as possible of it (1996:11). He is also of the opinion that the translator of the Peshitta Matthew used an adapted version of the Diatessaron in his translation.

Shedinger (1999:267) says that Joosten did not take the complete quotations into consideration, but only the words or phrases that could indicate agreement with the Old Testament Peshitta. After discussing a number of examples, his conclusion is that Tatian's dependence on the Old Testament Peshitta is not on a very solid foundation. Joosten (2001) responded to Shedinger by discussing a number of examples were the reading of the Diatessaron is attested by different source, both East and West. His conclusion remains the same as in the other two publications mentioned above.

As we do not have a Syriac text of the Diatessaron, the precise relationship between it and the later Syriac Gospels cannot be defined. However, this group of examples can be discussed without considering the issue of harmonisation, as these quotations only appear in Matthew. 


\section{Old Testament quotations in Matthew \\ Matthew 1:22-23, quoting Isaiah 7:14}

The use of the fulfilment quotation is unique to Matthew (Beaton 2005:64). The focus on these quotations because of the recurring introductory formula, is self-evident. The first one is found in Matthew 1:23.

Knowles (2006:72) distinguishes between texts that had an apocalyptic or messianic interpretation in the Judaism of the New Testament period and those in which such an interpretation has been unique to the church. Isaiah 7:14 was not interpreted messianically in Jewish exegesis (Beaton 2005:65-66). In the Christian church, however, the quotation of Isaiah 7:14 in Matthew 1:22-23 is probably one of the bestknown quotations in which the text from the Old Testament is used to explain the virgin birth of Jesus:

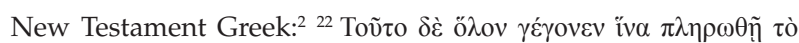

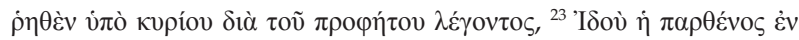

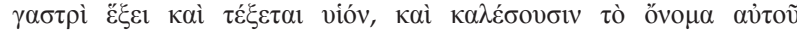

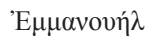

NIV: ${ }^{22}$ All this took place to fulfil what the Lord had said through the prophet: ${ }^{23}$ 'The virgin will conceive and give birth to a son, and they will call him Immanuel.' ${ }^{3}$

The first important point is to determine whether the New Testament quotes from the Hebrew or the Septuagint:

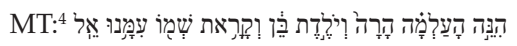

NIV: The virgin will conceive and give birth to a son, and she will call him Immanuel.

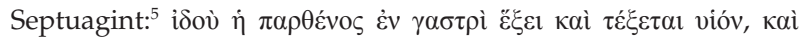

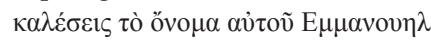

Menken: ${ }^{6}$ Behold, the virgin will be pregnant and will give birth to a son, and you will call his name Emmanuel.

Most scholars are of the opinion that the New Testament uses the text of the Septuagint as basis in this instance (cf. Hagner 1998:20; Knowles 2006:75). The only difference between the New Testament and the Septuagint is the third person form

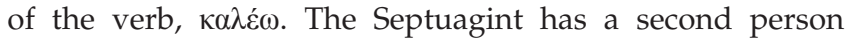
singular and the New Testament a third person plural (cf. Moyise 2001:40). Quite a number of witnesses to the Septuagint have this reading as well, mainly late manuscripts. Some New Testament witnesses have the reading of the Septuagint, starting with D (codex Bezae Cantabrigiensis, from the 5 th century). These readings could have been attempts on both sides to harmonise the reading with the other tradition.

2.The text of the Greek New Testament is in ail the examples taken from Aland et al. (2013)

3.In order to save space, the translation of the NIV will not be given for longer quotations from the Masoretic text and the New Testament Greek.

4.The Masoretic text is taken from Elliger and Rudolph (1984).

5.The text of the examples from Isaiah is taken from Ziegler (1967b).

6.Menken here refers to translations of passages from the Septuagint (Menken 2004).
The Hebrew has a third person feminine form here (cf. Wildberger 1991:308). The three verbs are all futures in the Greek, whilst the Hebrew has an adjective, a participle and a perfect with waw consecutive. The New Testament also follows the Septuagint with the translation of $\pi \alpha \rho \theta \varepsilon$ vos for הָעָלָָָָה (cf. Hagner 1998:20). This example and many of the other quotations in Matthew are discussed in detail by Maarten Menken (2004). He does not accept the idea that Matthew used the text of the Septuagint and changed the person of the verb. He (2004:121-124) discusses the textual problems in the Septuagint in detail and is of the opinion that Matthew used a revised text of the Septuagint for this quotation and did not alter the text he had to fit into his context (2004:125). However, the possibility of a revised Septuagint text does not have implications for the Syriac translation of the quotation.

The Old Testament Peshitta is the oldest of the four Syriac versions under discussion: ${ }^{7}$

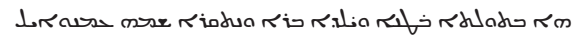

h' btwlt' bṭn' wyld' br' wntqr' šmh 'mnw'l

Look, the virgin has conceived and will give birth to a son and his name will be called Immanuel. ${ }^{8}$

This Syriac translation follows the Hebrew word order closely, but has some interesting renderings. It could have

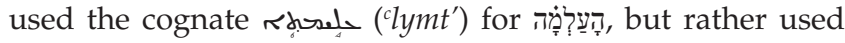
ralato (btwlt'). The reason is probably the influence of the Greek New Testament rendering of the Hebrew word with $\dot{\eta}$ $\pi \alpha \rho \theta \varepsilon \dot{v}$ os. This could be an example of an influence from the side of the New Testament Greek on the Peshitta Old Testament. This rendering is then followed by the later Syriac renderings in the Old Syriac Gospels and the New Testament Peshitta. The Old Testament Peshitta is also not consistent in its rendering of the Hebrew verbs in this passage. It renders the Hebrew adjective at the beginning of Isaiah 4:17 with a participle, the Hebrew participle with a participle and the Hebrew perfect with waw consecutive with an imperfect. The only other difference is the use of a passive verb ('his name will be called Immanuel') at the end:

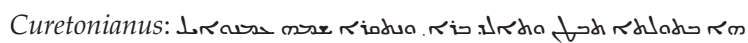

h' btwlt' tbṭn wt'ld br' wntqr' šmh 'mnw'l

Look, the virgin will conceive and give birth to a son and his name will be called Immanuel.

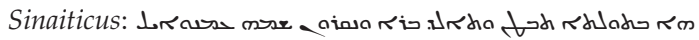

h' btwlt' tbṭn wt'ld br' wnqrwn' šmh 'mnw'l

Look, the virgin will conceive and give birth to a son and they will call his name Immanuel.

The two Old Syriac texts differ in one instance only and the influence of the Peshitta Old Testament is clear. They use the

7.The texts from the Old Testament Peshitta of Isaiah is taken from Brock (1987).

8.The English translations of the Syriac are the author's own. 
vocabulary of the Peshitta Old Testament, but have two imperfects for the first two verbs, instead of the perfect and participle of the Old Testament Peshitta. They do not follow the Greek idiom of the Septuagint and New Testament Greek for being pregnant, but use the verb of the Peshitta Old Testament. Sinaiticus uses the same passive verb at the end of the quotation as the Peshitta Old Testament does, whilst the Curetonianus uses the third person plural active verb, as the New Testament Greek does. It is quite evident that these two Syriac witnesses started with the rendering close to that of the Old Testament Peshitta and adapted it to some extent to the New Testament Greek.

What is also interesting to note is that in the introductory formula before the quotation Sinaiticus has not only 'through the prophet', but rather 'through Isaiah the prophet' Curetonianus has 'through the mouth of the prophet Isaiah'. In this they agree with the Greek manuscript D and the Itala:

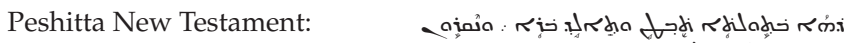

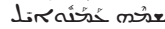
$d h^{\prime}$ btwlt' tbṭ wt'ld br' wnqrwn' šmh 'mnw'l

Look, the virgin will conceive and give birth to a son and they will call his name Immanuel.

The New Testament Peshitta agrees in every aspect with the Sinaiticus; thus, it probably did not change the Syriac basic text it used.

All the texts follow the word order of the Hebrew closely. As far as lexical items are concerned, the choice of $\pi \alpha \rho \theta \varepsilon \dot{v} v \varsigma$ in the Septuagint is very important. This is followed by the New Testament, and by the Syriac versions with ralato (btwlt'). Other important issues are the rendering of 'will become pregnant', where the Hebrew uses an adjective, the Septuagint and New Testament use a Greek idiom ( $\dot{\varepsilon} v \gamma \alpha \sigma \tau \rho \grave{~} \tilde{\varepsilon} \xi \varepsilon \imath)$, the Old Testament Peshitta has a participle, and the three New Testament Syriac versions use an imperfect of the same Syriac verb as the Old Testament Peshitta. In the Hebrew, the verb used for naming the boy is active and third person feminine. The Septuagint has a second person form. The New Testament has the verb in the third person plural, whilst the Old Testament Peshitta has a passive. The New Testament Peshitta has a third person plural, like the New Testament Greek. Curetonianus follows the Old Testament Peshitta, and Sinaiticus agrees with the New Testament Greek in the one instance where they differ. The New Testament Peshitta follows the Sinaiticus and the New Testament Greek in this instance.

\section{Matthew 2:15, quoting Hosea 11:1}

This example is interesting because of the way in which the New Testament applies a historical statement in the Old Testament to an event in the life of Jesus (cf. Menken 2004:133; Moyise 2001:41-42):

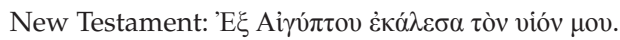

NIV: Out of Egypt I called my son.

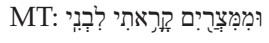

NIV: And out of Egypt I called my son.

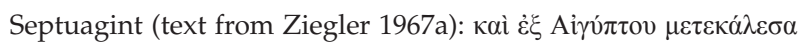

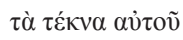

And from Egypt I called his children.

A comparison of the Hebrew and Greek Old Testament and the New Testament makes it quite clear that the New Testament follows the Hebrew here and not the Septuagint (cf. Hagner 1998:37-38; Menken 2004:135 mentions the possibility of a revised text of the Septuagint that had been used). The different verbs used for 'to call' already point in this direction. The reference at the end of the quotation makes it quite clear. The New Testament follows the Hebrew in the rendering of 'my son', whilst the Septuagint has 'his children'. The Masoretic text reads the singular of the noun with suffix first person singular ('my son'), whilst the Septuagint probably rendered a Hebrew text with a plural form of the noun and the third person masculine singular suffix ('his sons', or 'his children'). The difference in the unvocalised Hebrew would have been a waw at the end of the word. This could have been the result of dittography in the Hebrew, as the yod and waw looked quite the same in the time of the translation of the Septuagint:

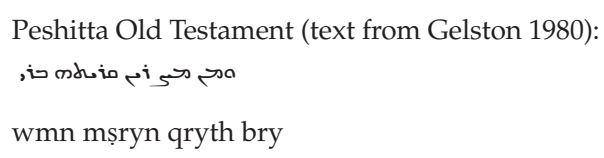

The Old Testament Peshitta follows the Hebrew, with just the addition of a suffix to the verb, following the normal Syriac idiomatic style:

$$
\begin{aligned}
& \text { Curetonianus: : } \\
& \text { dmn mṣryn qryt lbry } \\
& \text { From Egypt I called my son. }
\end{aligned}
$$

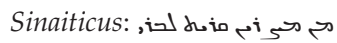

$$
\begin{aligned}
& \text { mn mṣryn qryt lbry } \\
& \text { From Egypt I called my son. }
\end{aligned}
$$

The only difference between these two texts is the $x$ at the beginning of the quotation, an inner-Syriac variant for indicating direct speech. Although the two texts use the same vocabulary as the Peshitta Old Testament, there are two differences, namely the omission of the suffix to the verb and the addition of the preposition, $\lrcorner$, before the object of the verb:

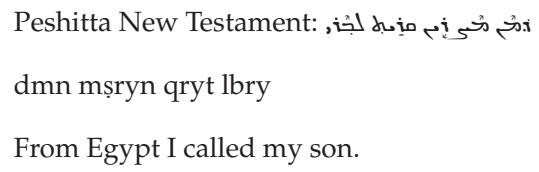

The Peshitta New Testament agrees with the Curetonianus in this instance, with the $x$ at the beginning of the quotation. 


\section{Matthew 2:18, quoting Jeremiah 31:15}

The quotation of Jeremiah 31:15 in Matthew 2:18 is longer than the quotations in the two previous examples:

New Testament:

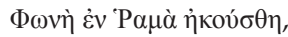

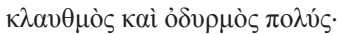

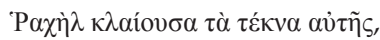

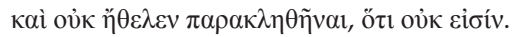

NIV: A voice is heard in Ramah, weeping and great mourning, Rachel weeping for her children and refusing to be comforted, because they are no more.

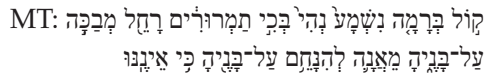

NIV: A voice is heard in Ramah, mourning and great weeping, Rachel weeping for her children and refusing to be comforted, because they are no more.

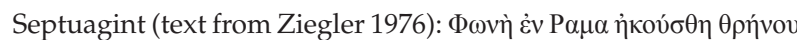

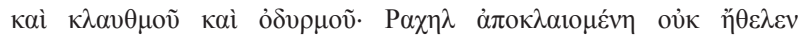

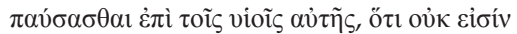

Menken: A voice was heard in Ramah of wailing and weeping and lamentation: Rachel's weeping would not cease for her sons, because they are no more.

The relationship between the quotation and the two Old Testament texts is not quite clear. The Masoretic text refers to the children of Rachel twice. The Septuagint has only the second reference. The Septuagint has kai before the second and third nouns, which refer to mourning; it has these three nouns in the genitive, connecting them to the sound at the beginning of the statement; and it follows the Hebrew word order. The use of the genitive is perhaps epexegetical to describe the sound referred to at the beginning. This is a specific interpretation of the Hebrew. The Greek New Testament has only two nouns, which agree with the second and third nouns of the Septuagint. Some manuscripts have the three nouns, but it could be ascribed to an attempt to harmonise the quotation with the Septuagint Jeremiah. The $\pi \mathrm{o} \lambda \dot{ }{ }^{\prime} \varsigma$ added to the second noun might have been an attempt in a literal translation to render the final word of the three in the Hebrew; a word that occurs only three times in the Hebrew Old Testament (twice in Jeremiah). The Greek New Testament has the first reference to Rachel's children but not

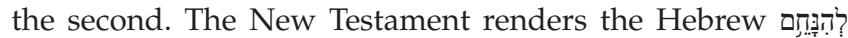
['to be comforted'] with $\pi \alpha \rho \alpha \kappa \lambda \eta \theta \tilde{\eta} v \alpha r$ ['to encourage'; 'to console'], a better translation than the $\pi \alpha v$ $\sigma \alpha \sigma \theta \alpha 1$ ['to cease'; 'to stop'] of the Septuagint. Both the New Testament and the Septuagint have ov่к $\ddot{\eta} \theta \varepsilon \lambda \varepsilon v$ ['not wanting'] for the Hebrew

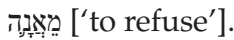

Menken $(2000 ; 2004)$ discusses this text in detail. He makes it clear that the text in the Septuagint was transmitted in two different forms (Menken 2004:143-145). He is of the opinion that Matthew used a revised version of the Septuagint as his base text (2004:158-159). The revision entails a better translation of the Hebrew and an adaptation of Jeremiah to Genesis 37:35 (Menken 2000:125). It is also true that Matthew ignores the original context of the text in Jeremiah in his use of the quotation (cf. Moyise 2001:42-43).

The Peshitta of the Old Testament has a few interesting readings:

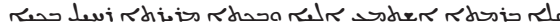

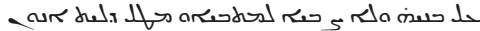

$$
\begin{aligned}
& q^{\prime} l^{\prime} b r m t^{\prime} \text { 'štm ' 'ly' wbkt' mryrt' rhyl bky' cl bnyh wl' șby' } \\
& \text { lmtby'w mtl dlyt 'nwn }
\end{aligned}
$$

A voice is heard in Ramah, lamentation and bitter weeping. Rachel is weeping over her children and she is not willing to be comforted because they are no more.

It adds 'and' between the first two nouns indicating mourning. However, it translates the third noun as an adjective with the second noun, 'bitter weeping'. It uses a similar phrase as the Greek New Testament for the Hebrew

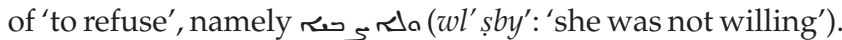
Like the Greek, it has the first reference to Rachel's children, but not the second. It is possible that this translation could have been influenced by the Greek New Testament's version. The Septuagint has the second occurrence of 'her children', and not the first one. The Greek New Testament and the Old Testament Peshitta have the first one and not the second one.

The contents of the two witnesses to the Old Syriac New Testament are exactly the same, but there are minor differences in the Syriac idiom:

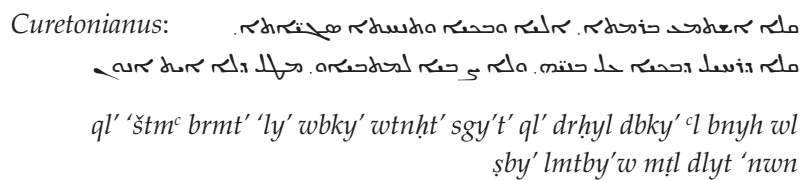

A voice is heard in Ramah, lamentation and weeping and much groaning, the voice of Rachel weeping over her children and she is not willing to be comforted because they are no more.

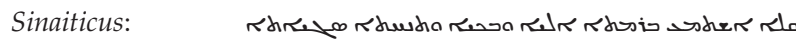

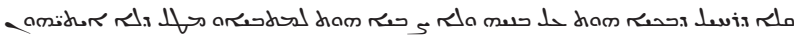
$q l^{\prime}$ 'štm $b r m t^{\prime}$ 'ly' wbkt' wtnht' sgy't't ql' drhyl dbky' hwt cl bnyh wl şby' hwt lmtby'w mṭl dl' 'ytyhwn

A voice is heard in Ramah, lamentation and weeping and groaning, the voice of Rachel weeping over her children and she is not willing to be comforted because they are no more.

Sinaiticus adds 'to be' twice to participles. They have different constructions for the final phrase, namely Sinaiticus adds a suffix to the particle $\mathrm{w}^{\mathrm{s}}$ ('yt) and Curetonianus uses the independent personal pronoun ('nwn). However, they share a number of unique readings. Both of them have the first verb in the quotation as the second word in the sentence, not as the third word. They both have three nouns for the mourning, with 'and' before the second and third. They both add 'great' to the third noun, partly agreeing with the New Testament Greek and partly with the Old Testament Peshitta and the Hebrew. Both of them begin the second part of the quotation with ملم aive (ql'drhyl dbky'; 'The voice of Rachel that is 
weeping'), repeating the word at the beginning of the quotation. Both of them only have the first reference to Rachel's children. In the end, these two texts have a unique combination of features from three different sources.

The New Testament Peshitta is very interesting in this instance:

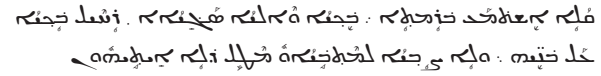

$\mathrm{ql}^{\prime}$ 'štm brmt' bkt' w'ly' sgy" rḥyl bky' cl bnyh wl' șby' lmtby'w mṭl dlyt 'ytyhwn

A voice is heard in Ramah, weeping and great lamentation. Rachel is weeping over her children and she is not willing to be comforted because they are no more.

The New Testament Peshitta clearly starts with a text very similar to the Curetonianus, as can be seen from the word order at the beginning. However, it did edit that text to bring it closer to the Greek, as can be seen from the two nouns that refer to mourning and the adjective that is added to the second. It omits the repetition of 'voice' and the final phrase agrees with the Sinaiticus. In this instance, the New Testament Peshitta used the vocabulary of the Old Syriac as a starting point but revised it to come closer to the Greek.

\section{Matthew 4:15-16, quoting Isaiah 8:23-9:1}

This is again quite an extensive quotation, starting not with the beginning of the first sentence in the Masoretic text, but with the reference to the region of Zebulon and Naphtali, which is the main point of the quotation. The Masoretic text and the Septuagint show some important differences. Menken (2004:15-33) discusses this example in detail, concluding that Matthew used a revised version of the Septuagint as his base text. Knowles (2006:67-68) indicates that the quotation shares elements of the Hebrew and the Greek, but that it has a few unique features as well:

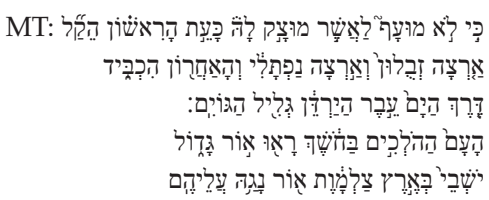

NIV: Nevertheless, there will be no more gloom for those who were in distress. In the past he humbled the land of Zebulon and the land of Naphtali, but in the future he will honour Galilee of the nations, by the Way of the Sea, beyond the Jordan

The people walking in darkness have seen a great light; on those living in the land of deep darkness a light has dawned.

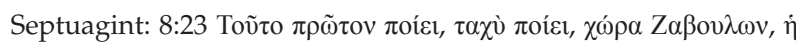

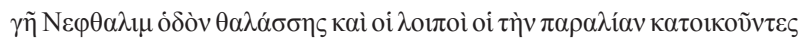

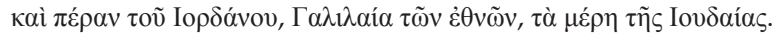

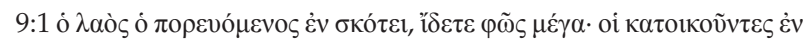

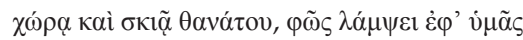

Menken:

Do this first, do it fast, land of Zebulon, land of Naphtali, toward the sea and the rest who dwell at the seashore and beyond the Jordan, Galilee of the Gentiles, districts of Judah.
You people that walk in darkness, see, a great light, you who dwell in the region and the shadow of death, light will shine upon you.

In the section that the New Testament quotes from Isaiah 8:23, the Septuagint places the verb first, repeats it and makes the verbs imperatives directed at Zebulon and Naphtali, whilst the Hebrew talks about what the Lord did to them. The Septuagint translates the two occurrences of ארָָָּה in the Hebrew in Isaiah $8: 23$ with different words. The Septuagint also has a reference to those living by the seashore and to the whole of Judah. In Isaiah 9:1, the Septuagint renders the verb 'to see' as an imperative, whereas the MT has a perfect. Since the Septuagint translated an unvocalised text, reading an imperative is possible. This reading is perhaps the reason for the reference to 'you' at the end of the verse, against the 'them' of the MT. It is interesting to

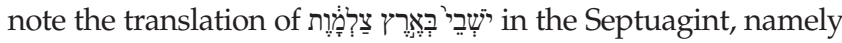

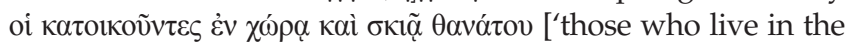
land and the shade of death'], where the one construct phrase of the Hebrew is rendered by two phrases.

The quotation reads as follows in Matthew 4:15 and 16:

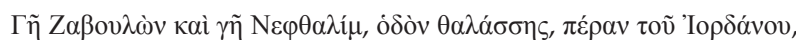

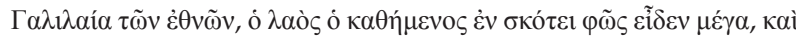

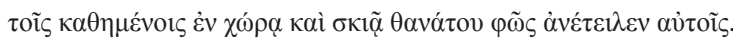

NIV: Land of Zebulon and land of Naphtali, the way of the Sea, beyond the Jordan, Galilee of the Gentiles - the people living in darkness have seen a great light; on those living in the land of the shadow of death a light has dawned.

The quotation does not have a verb at the beginning, but for the rest it agrees with the Masoretic text and not the Septuagint in Isaiah 8:23. It also follows the MT in Isaiah 9:1. It agrees with the rendering of the Septuagint of

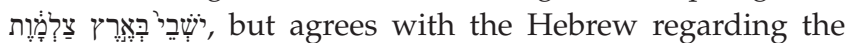
form of the verbs. It does not translate 'land' differently in the first part of the quotation and it uses a different verb at the end of the quotation. In this instance, the New Testament does not quote directly from the Septuagint, but it has a combination of unique features.

The Peshitta Old Testament differs from the Hebrew only in two instances in Isaiah 8:23. Firstly, it reads riwaro ( $\left.w^{\prime} w h d n^{\prime}\right)$ for daleth for a resh, as both letters are similar in Hebrew and in Syriac. Secondly, it adds rims (nhr' - 'river') to the Jordan. Isaiah 8:1 follows the Hebrew quite closely:

Peshitta Old Testament:

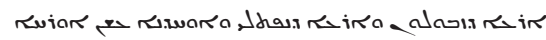
ת.

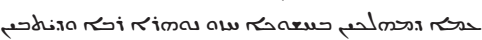

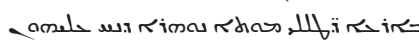

' $\mathrm{r}^{\mathrm{c}}$ dzbwlwn $\mathrm{w}^{\prime} \mathrm{r}^{\mathrm{c}}$ ' dnptly $\mathrm{w}^{\prime} w \mathrm{w}_{\mathrm{d}} \mathrm{n}^{\prime}$ 'šn 'wrḥ' dym' cbrwhy dyrdnn nhr' glyl' d'mm' ${ }^{c} m^{\prime}$ dmhlkyn bḥšwk' ḥzw nwhr' rb' wdytbyn b' $\mathrm{r}^{\mathrm{c}^{\prime}}$ dṭlly mwt' nwhr' dnḥ clyhwn

Land of Zebulon and the land of Naphtali, and the dominion prevailed, the way of the Sea, beyond the River Jordan, Galilee of the nations - 
The people walking in darkness

have seen a great light;

those living in the land of the shadows of death,

a light has risen upon them.

The two manuscripts of the Old Syriac have some minor differences, mainly related to the Syriac idiom, but also some important variants:

Curetonianus:

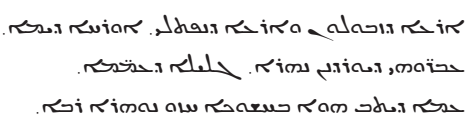

${ }^{c} m^{\prime}$ dytb hw' bhšwk' hzw nwhr' rb' w'ylyn dytbyn hww bțll' dmwt' nwhr' $r b^{\prime}$ dnh clyhwn

Land of Zebulon and the land of Naphtali, the way of the Sea, beyond the River Jordan, Galilee of the nations -

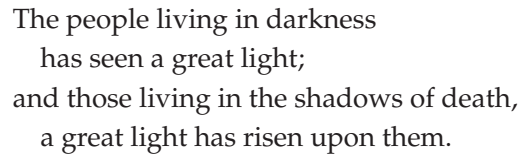

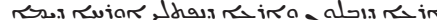

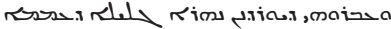

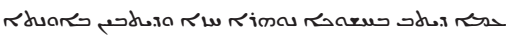

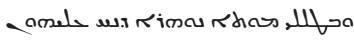

' $r^{c}$ dzbwlwn w'rc' dnptly 'wrh' dym' cbrwhy dyrdnn nhr' glyl' d'mm' ${ }^{c} m^{\prime} d y t b$ bhšwk' nwhr' hiz' wdytbyn b'wnt' wbțlly mwt' nwhr' dnh clyhwn

Land of Zebulon and the land of Naphtali, the way of the Sea, beyond the River Jordan, Galilee of the nations -

The people living in darkness

has seen a light;

and those living in the place and the shadows of death,

a light has risen upon them.

The two Old Syriac texts follow the vocabulary of the Old Testament Peshitta in most cases, but adapt it in line with the Greek New Testament. They omit the phrase omitted in the Greek New Testament in verse 15. They follow the Old Testament Peshitta by adding "river" to the Jordan in verse 15.

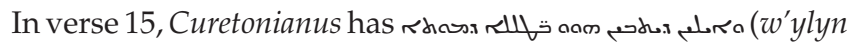

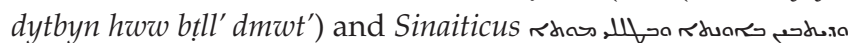
(wdytbyn $b^{\prime} w n t^{\prime}$ wbtlly $m w t^{\prime}$ ). The important difference here is

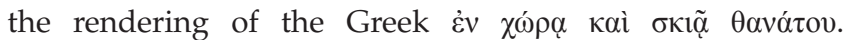
Curetonianus follows the Old Testament Peshitta, while Sinaiticus following the Greek says, 'in the place and the shades of death'.

Curetonianus reads "a big light" twice in verse 16 and Sinaiticus only "a light" in both instances. Sinaiticus follows the Greek word order in the first instance by placing "a light" before the verb. Curetonianus adds the verb "to be" to the two participles in verse 16 .
It is impossible to determine on the balance of evidence provided by this quotation alone whether Sinaiticus was revised to bring it in line with the Greek or whether Curetonianus was revised to bring it in line with the Peshitta Old Testament.

The Peshitta New Testament has the same text as Curetonianus in verse 15, except for the addition of "river" to the Jordan, where it follows the Greek. In verse 16, it follows the word order of Sinaiticus (and the Greek), but retains the "big light". In the last part of the verse, it follows the rendering of the Greek, like Sinaiticus, but uses the word ridir $\left(b^{\prime} \operatorname{tr}^{\prime}\right)$ it is again clear that this text was edited to bring it closer to the Greek:

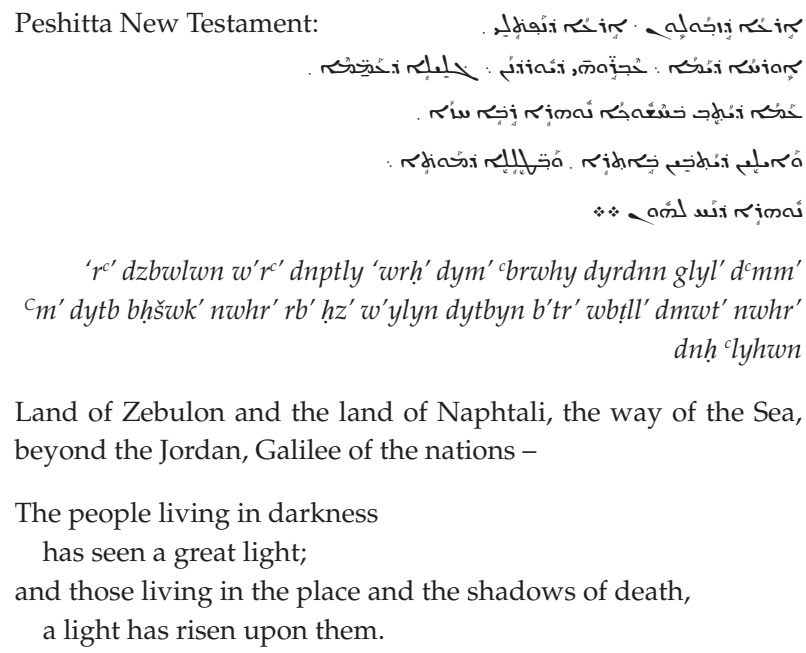

' $r$ ' dzbwlwn w' $r^{c}$ dnptly 'wrh' dym' cbrwhy dyrdnn glyl' d'mm'

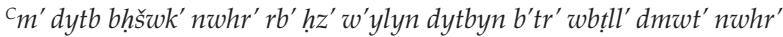

Land of Zebulon and the land of Naphtali, the way of the Sea, beyond the Jordan, Galilee of the nations -

The people living in darkness

has seen a great light:

and those living in the place and the shadows of death, a light has risen upon them. dnh clyhwn

\section{Matthew 8:17, quoting Isaiah 53:4}

This quotation is shorter than the previous one:

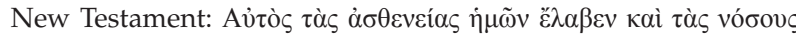
$\dot{\varepsilon} \beta \alpha ́ \sigma \tau \alpha \sigma \varepsilon v$.

NIV: He took up our infirmities and bore our diseases.

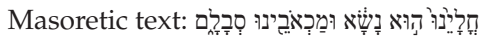

NIV: Surely he took up our pain and bore our suffering.

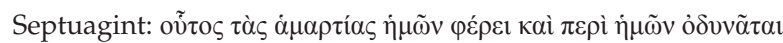

Menken: He took our sicknesses, and carried our diseases.

It is quite evident that the New Testament follows the Masoretic text in this instance. Beaton (2005:69) thinks the translation might have been Matthew's. Menken (2004:36) says that this New Testament quotation does not follow the more spiritualised version of the Septuagint, although he again tends to favour a revised base text of the Septuagint (2004:48). The translation does not render the object suffix to the second verb. The Septuagint has 'sins' for 'sicknesses' and it translates the next verse quite free, whilst the New Testament retains the noun as in the Masoretic text.

The Old Testament Peshitta follows the Masoretic text, except for the object suffix to the final Hebrew verb. It adds the personal pronoun, third person, masculine singular to the second phrase: 


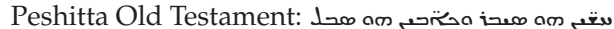

ḥšyn hw sybr wk'byn hw sbl

Our suffering He bore and our pain he carried.

The two witnesses to the Old Syriac differ only in one

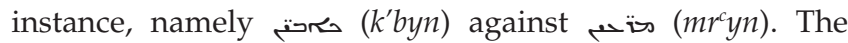
words are synonyms. Their translation is independent of the Old Testament Peshitta and they do not follow the word order of any of the older texts:

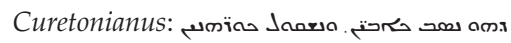

dhw nsb k'byn wnšqwl kwrhnyn

For he took our pain and he carried our diseases.

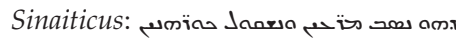

dhw nsb mrcyn wnšqwl kwrhnyn

For he took our illnesses and he carried our diseases.

The Peshitta New Testament has the same first phrase as the Old Syriac, using the word for 'pain', like Curetonianus; however, it changes the word order of the second phrase and uses a different verb, but again a synonym:

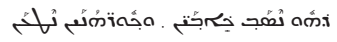

dhw nsb k'byn wkwrhnyn nț ${ }^{c} n$

For he took our pain and he carried our diseases.

It is clear that the Peshitta New Testament used a text similar to Curetonianus, but revised it slightly to bring the word order closer to the New Testament Greek.

\section{Matthew 12:18-21, quoting Isaiah 42:1-4}

This is quite an extended quotation that cannot be discussed in detail here. Because of the length, the translations are not given:

New Testament:

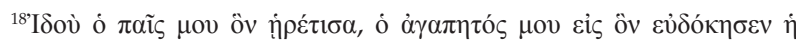

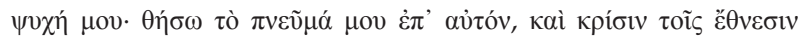
$\dot{\alpha} \pi \alpha \gamma \gamma \varepsilon \lambda \varepsilon \tilde{\varepsilon}$.

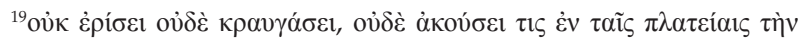

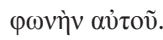

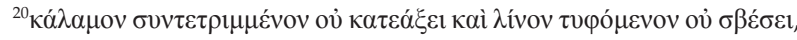

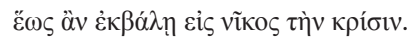

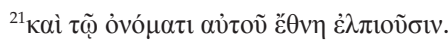

MT:

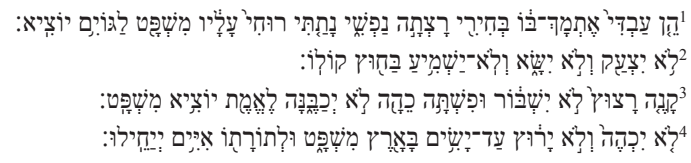

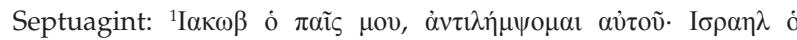

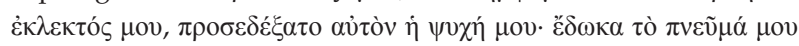

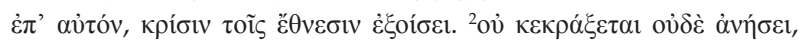

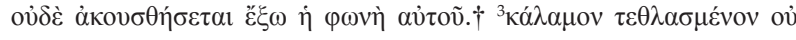

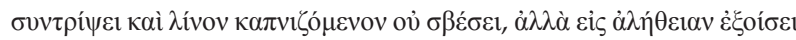

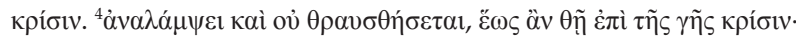

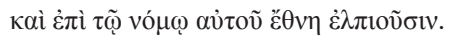

Menken:

${ }^{1}$ Jacob my servant, I shall uphold him, Israel my chosen, my soul has accepted him;

I have given my Spirit upon him,

He will bring forth justice to the gentiles.

${ }^{2}$ He will not shout or raise (his voice),

nor will his voice be heard outside.

${ }^{3}$ He will not break a shattered reed

And he will not quench a smoking wick,

But faithfully he will bring forth justice.

${ }^{4}$ He will flame up and not be shattered,

Until he sets justice on earth,

And in his name the gentiles will hope.

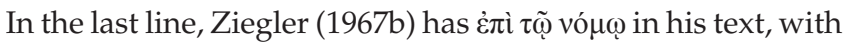
many witnesses supporting غ̇ंì $\tau \tilde{\omega}$ ỏvó $\mu \alpha \tau$ (followed by Menken in his translation). This is clearly an inner-Greek variant, with the New Testament in Greek following many witnesses in reading 'name', and not 'law'. The reading with 'law' occurs in the Old Testament Peshitta, but all three the Syriac Gospels have 'name'.

Without going into every detail, it is quite evident that Matthew does not use the Septuagint in this instance. There are many differences between the texts (cf. Beaton 2005:7072; Menken 2004:51). The translation could probably be his own from the Hebrew (cf. Hagner 1998:336). The New Testament, however, does not quote the whole of Isaiah 42:14 , and reads 'nations' for 'islands' in the last quoted line.

The Peshitta Old Testament follows the Hebrew quite closely, although minor differences in vocabulary and word order occur:

Peshitta Old Testament:

$$
\begin{aligned}
& \text { " } \\
& \text {. }
\end{aligned}
$$

${ }^{1}$ Look at my servant whom I support, my chosen one, in whom my soul delights, I have given my spirit upon him who will bring justice to the nations.

${ }^{2} \mathrm{He}$ will not shout and he will not cry out and not let his voice be heard on the street.

${ }^{3} \mathrm{~A}$ bruised reed he will not break and a flickering wick he will not quench. In faithfulness he will bring justice forth. 
${ }^{4} \mathrm{He}$ will not falter or flicker until he establishes justice on earth. On his teaching (law) the islands will hope.

The two Old Syriac witnesses are quite close to one another. In Matthew 12:19, Sinaiticus omits ros (b̌̌wq'). In verse 20, the Sinaiticus has the Ethpeel and Curetonianus the Peal of the same verb. At the end of verse 21, Sinaiticus has the last two words in the same order as the Greek, and Curetonianus has the reverse order. The two texts have very few agreements with the Peshitta Old Testament, making it clear that they translated from the Greek:

Curetonianus:

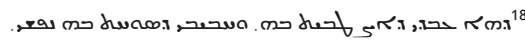

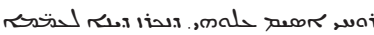

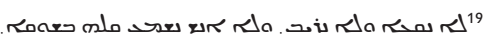

$$
\begin{aligned}
& \text { م Rم }
\end{aligned}
$$

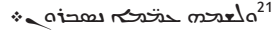

$$
\begin{aligned}
& { }^{18} d h^{\prime} \text { c bdy d'ștbyt bh whbyby dswht bh npšy rwhy 'sym clwhy dnkrz } \\
& \text { dyn' }{ }^{c} m m^{\prime} \\
& { }^{19} l^{\prime} n q^{c^{\prime}} w l^{\prime} n r y b w l^{\prime} \text { 'nš nšm }{ }^{c} \text { qlh bšwq' } \\
& { }^{20} q_{n y} y^{\prime} y^{c^{\prime}} l^{\prime} \text { nttbr wšrg' dmtptp l' ndckc } d m^{\prime} \text { dnpq dyn' lzkwt' } \\
& { }^{21} \text { wlšmh }{ }^{c} m m^{\prime} \text { nsbrwn }
\end{aligned}
$$

${ }^{18}$ For look at my servant whom I delight in, my beloved, whom my soul desires, I have put my soul upon him who will proclaim justice to the nations.

${ }^{19}$ He will not shout and he will not cry out and nobody will hear his voice in the street.

${ }^{20} \mathrm{~A}$ bruised reed will not be broken and a flickering wick he will not quench until justice goes forth to victory.

${ }^{21}$ On his name the nations will hope.

\section{Sinaiticus:}

$$
\begin{aligned}
& \text { م } \\
& \text { (19 }{ }^{19}
\end{aligned}
$$

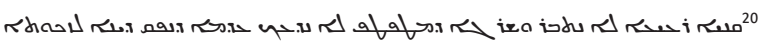

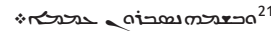

$$
\begin{aligned}
& { }^{18} \text { h ... 'ștbyt... bh ... rwhy 'sym clwhy dnkrz dyn' lcmm' } \\
& { }^{19} l^{\prime} n q^{c^{\prime}} w l^{\prime} n r y b w l^{\prime \prime} \text { 'nš } n s ̌ m m^{c} \text { qlh } \\
& { }^{20} q_{n y y^{\prime}} r^{c} y^{c^{\prime}} l^{\prime} n t b r \text { wšrg' dmṭtp } l^{\prime} n d^{c} k^{c} d m^{\prime} d n p q d y n^{\prime} l z k w t^{\prime} \\
& { }^{21} \text { wlšmh 'mm' nsbrwn }
\end{aligned}
$$

${ }^{18}$ Look ... I delight in ... I have put my soul upon him who will proclaim justice to the nations.

${ }^{19} \mathrm{He}$ will not shout and he will not cry out and nobody will hear his voice.

${ }^{20} \mathrm{~A}$ bruised reed he will not break and a flickering wick he will not quench until justice goes forth to victory.

${ }^{21}$ On his name the nations will hope.

In Matthew 12:21 the verb 'to break' is active in the Sinaiticus and passive in the Curetonianus. The Leiden Old Testament Peshitta has the active in the text, but notes that the Syriac manuscript 7a1 has the passive:
Peshitta New Testament:

$$
\begin{aligned}
& \text {, }
\end{aligned}
$$

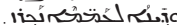

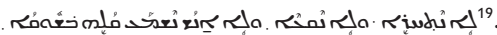

${ }^{18}$ Look at my servant whom I delight in, my beloved, whom my soul desires, I have put my soul upon him. He will proclaim justice to the nations.

${ }^{19}$ He will not argue nor shout out and nobody will hear his voice in the street.

${ }^{20}$ A bruised reed he will not break and a flickering wick he will not quench until justice goes forth to victory.

${ }^{21}$ On his name the nations will hope.

The Peshitta New Testament follows the Old Syriac in most respects. However, at the end of Matthew 12:18, it follows the word order of the Greek, whereas the Old Syriac places the verb first. It has a different translation for the beginning of verse 19, with the first verb of the Old Syriac in the second position and a different verb at the beginning. This is indeed

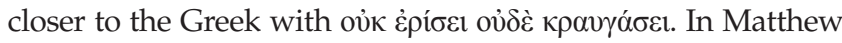
12:20, it agrees with Sinaiticus and the Greek with the active verb isd. (ntbr). The word order in Matthew 12:21 agrees with the Greek and Curetonianus, although the preposition with (wbšmh) agrees with the Sinaiticus. It is quite clear that this text was edited to bring it in line with the Greek New Testament.

\section{Matthew 13:35, quoting Psalm 78 (77):2}

This quote is interesting in the sense that the first part agrees with the Septuagint, especially with regard to the plural noun against the singular of the MT. The second part is, however, an independent translation of the Hebrew, with an addition ('from the beginning of the world'). The Septuagint is close to the Hebrew, with the exception of the plural noun in the first line, probably influenced by the plural noun in the second part of the verse. This quotation is discussed in detail by Menken (2004:89-104), who again sees the quotation as coming from a revised text of the Septuagint:

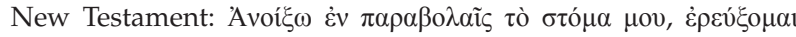

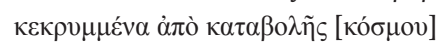

NIV: I will open my mouth in parables, I will utter things hidden since the creation of the world.

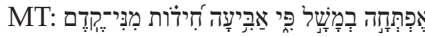

NIV: I will open my mouth with a parable; I will utter hidden things, things from of old 


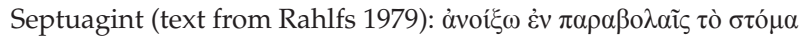

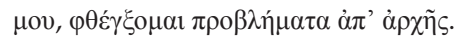

Menken: I will open my mouth in parables, I will utter riddles from the beginning.

The Old Testament Peshitta (text from Walter 1980) has a plus at the beginning of the first part ('Look then') and it has the first noun in the plural (although that is just through the seyame). In the second part, it uses a generic verb ('to speak'). It is a good rendering of the Hebrew, following the Hebrew word order as well:

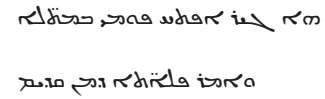

h' gyr 'ptḥ pwmy bmtl' w'mr pl't' dmn qdm

Look then, I will open my mouth with parables, and I will speak proverbs from the beginning.

The two witnesses of the Old Syriac differ only with regard to the verb of the second part of the quotation, where Curetonianus uses the same verb as the Old Testament Peshitta, and Sinaiticus a synonym. They differ from the Old

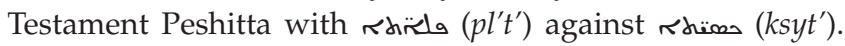
Their rendering of this word follows the Greek against the Hebrew and the Septuagint. The final phrase, however, agrees with the Hebrew Old Testament, the Septuagint and the Peshitta Old Testament, and does not follow the interpretation and addition of the Greek New Testament:

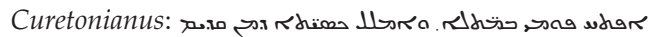

'ptḥ pwmy bmtl' w'mll ksyt' dmn qdym

I will open my mouth with parables, and I will speak hidden things from the beginning.

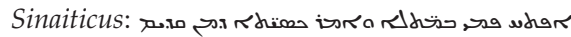

'pth pwmy bmtl' w'mr ksyt' dmn qdym

The reading of the New Testament Peshitta is very interesting in this instance:

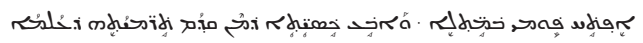

'pth pwmy bmtl' w'bc ksyt' dmn qdm trmyth d'lm'

I will open my mouth with parables, and I will utter hidden things from before the creation of the world.

The first part agrees with the other three Syriac texts. At the beginning of the second part, it uses the verb the same verbal root as the Hebrew. Is it possible that the translator looked at the Hebrew as well? The object and prepositional phrase following the verb are almost the same as in the Old Syriac, just changing 'the beginning' to 'before'. It then adds a translation of the final part of the quotation in the Greek New Testament. The translator did not want to omit the final part of his Syriac source text, but wanted to retain the interpretation of the New Testament as well. The final part of the quotation in the Peshitta New Testament reflects a complex rendering by the translator, quite unique in these quotations.

\section{Matthew 21:5, quoting Isaiah 62:11; Zechariah 9:9}

The quotation in the New Testament combines two texts from the Old Testament:

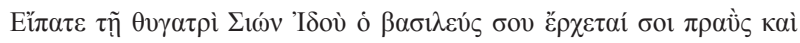

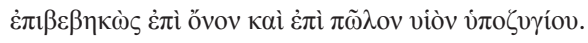

NIV:

Say to Daughter Zion,

'See, your king comes to you,

gentle and riding on a donkey,

and on a colt, the foal of a donkey.'

The first part of the quotation comes from Isaiah 62:11, and there is no difference in the rendering of all the texts discussed here.

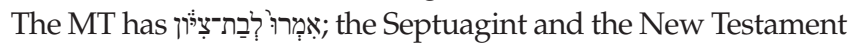

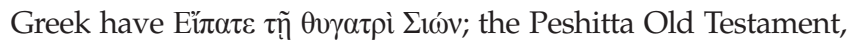
Curetonianus and the Peshitta New Testament all have div loisr ams ('mrw lbrt shywn; 'say to the daughter of Zion').

The second part of the quotation is from Zechariah 9:9. The Masoretic Text reads:

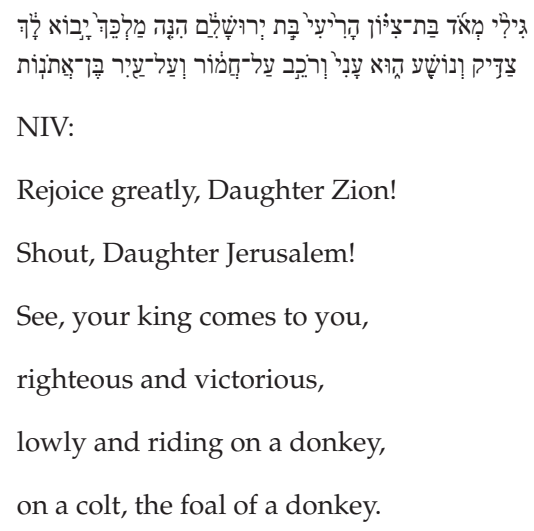

The part of the verse quoted in the New Testament is as follows in the Septuagint (text from Ziegler 1967a):

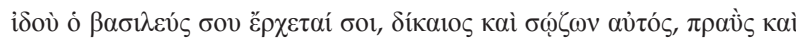

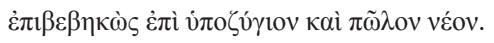

Menken:

Behold, your king is coming to you,

Righteous and saving is he,

meek and riding on a beast of burden

And on a young colt.

The only interesting translation is the final phrase, with кai

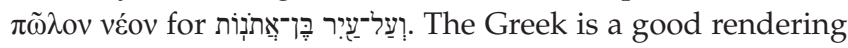
of the Hebrew, without being a word for word translation. The New Testament is close to the Septuagint, although 


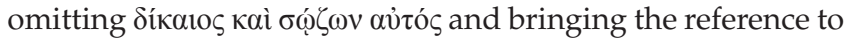
the ass more in line with the Hebrew.

The translation of the Old Testament Peshitta of Zechariah 9:9 (text from Gelston 1980) follows the Hebrew word for word, except for omitting the personal pronoun after roais $($ prwq'):

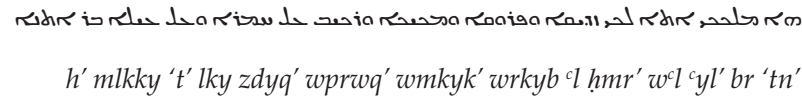

Look, your king is coming to you, righteous and a saviour, and humble and riding on an ass, the young one of a she-ass.

Sinaiticus lacks this section of Matthew. Curetonianus retains the 1 . $(z d y q)$ of the Old Testament Peshitta against the New Testament Greek. It has an Aphel perfect for the passive participle ick (rkyb) of the Old Testament Peshitta and the Greek:

Curetonianus: 'mrw lbrt' șhywn h' mlkky 't' lky zdyq wmkyk w'rkyb cl hmr' w' lcyl'br 'tn'

Say to the daughter of Zion: Look, your king is coming to you, righteous and humble and riding on an ass, the young one of a she-ass.

The New Testament Peshitta follows the Greek New Testament in omitting o $0 . x(z d y q w)$ and it has the passive participle (wmkyk), like the Old Testament Peshitta $\left(w m k y k^{\prime}\right)$. It was edited to bring it in line with the Greek New Testament:

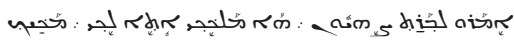
.

'mrw lbrt' șhywn h' mlkky 't' lky mkyk wrkyb cl hmr' wcl cyl' br 'tn'

Say to the daughter of Zion: Look, your king is coming to you, righteous and humble and riding on an ass, the young one of a she-ass.

\section{Matthew 27:9-10, quoting Zechariah 11:12-13}

The final quotation to be discussed is found in Matthew 27:9-10. It is ascribed to Jeremiah, but it partly corresponds to Zechariah 11:12-13. It takes two sections from Zechariah and puts them in reverse order between sections that cannot really be ascribed to this Old Testament passage. There is also a change of subject, as the relevant section is in the first person, with the prophet speaking, whilst the Greek New Testament has a third person plural subject:

The New Testament reads as follows:

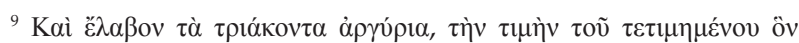

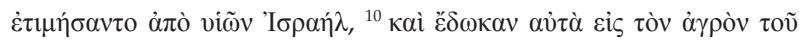

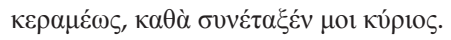

NIV: ${ }^{9}$ They took the thirty pieces of silver, the price set on him by the people of Israel, ${ }^{10}$ and they used them to buy the potter's field, as the Lord commanded me.
The Old Syriac is only available in Sinaiticus:

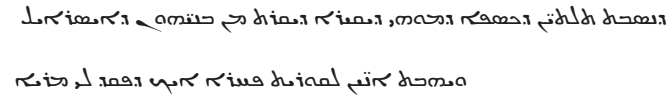

I took the thirty pieces of silver, the price of the precious one that I was estimated by the children of Israel and I gave them for the field of the potter as the Lord commanded me.

The translation follows the New Testament Greek as far as the basic contents are concerned. However, it has the verbs in the first person singular, as in the Peshitta of the Old Testament:

New Testament Peshitta:

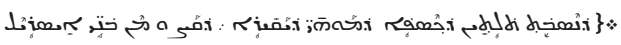

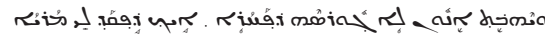

dnsbt tltyn dksp' dmwhy dyqyr' dqșw mn bny 'ysr'yl wyhbt 'nwn l'gwrsh dphr' 'yk dpqd ly mry'

I took the thirty pieces of silver, the price of the precious one, that they agreed from the children of Israel and I gave them for the field of the potter as the Lord commanded me.

The New Testament Peshitta is slightly different. It uses the

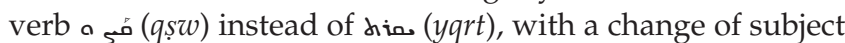
to the third person plural. For the field of the potter, it uses the Greek loanword moin $ه\left(l^{\prime}\right.$ gwrsh $)$, which corresponds to the word used in the Greek New Testament. In the first instance, it does not follow the Greek pattern of using the same verb twice; and in the second instance, it uses a Greek loanword bringing it closer to the Greek.

\section{Conclusion}

In the examples discussed, the Greek New Testament did not make much use of the Septuagint as it is known today. Menken is of the opinion that Matthew used a revised text of the Septuagint, but it is very difficult to prove this assumption in the instances discussed. In some instances the quotation in the Greek New Testament is closer to the Hebrew (Mt 2:15; 8:17), in some instances it is closer to the Septuagint (Mt 1:23; 13:35; 21:5) and in some instances it is a combination of both (Mt 4:15-16).

The Old Testament Peshitta had an influence on the Old Syriac, but not to the same extent in all instances. In some examples, the whole quotation is quite close to the Old Testament Peshitta (Mt 1:22-23; 4:15-16; 21:5), whilst no direct influence can be demonstrated in other instances (Mt 8:17, where the Old Syriac is a translation of the Greek). In some instances the deviation from the Old Testament Peshitta can be ascribed as an attempt to bring the Syriac closer to the Greek New Testament (Mt 2:15; 27:9-10). In Matthew 12:18-21 the Old Syriac follows the Greek New Testament. In Matthew 13:35 the word order of the Old Syriac is quite close to the Greek New Testament, but it does not have the plus of the Greek New Testament.

In instances where the Curetonianus and the Sinaiticus differ, it could demonstrate attempts to bring the text closer to the Greek New Testament (Curetonianus in Mt 1:23). 
The New Testament Peshitta normally started with a text close or similar to the Old Syriac (probably the Diatessaron according to Joosten and others), but frequently adapted it to bring it closer to New Testament Greek (Mt 1:23; 2:18; 4:15-16; 12:18-21; 21:5). In Matthew 2:15 the Peshitta New Testament has the same reading as the Old Syriac. In Matthew 8:17 the Peshitta New Testament adapted the reading of the Old Syriac to the Greek New Testament. There is one example of possible influence of the Hebrew text (Mt 13:35) and a few examples that show a combination of influences from the Old Syriac and the New Testament Greek (Mt 13:35; 27:9-10). It is clear that the New Testament Peshitta adapted its text more to the Greek New Testament than the Old Syriac, but the many places of agreement with the Old Syriac points to some contact between the two versions. This is especially true of those instances where the Old Syriac and New Testament Peshitta agree, but differ from the Old Testament Peshitta. These examples raises the question whether Tatian used the Old Testament Peshitta in all the quotations from the Old Testament.

\section{Acknowledgements Competing interests}

The author declares that he has no financial or personal relationship(s) that may have inappropriately influenced him in writing this article.

\section{References}

Aland, K., Aland, B., Karavidopoulos, J., Martini, C.M. \& Metzger, B.M., 2013, Novum Testamentum Graecum, 28th edn., Deutsche Bibelgesellschaft, Stuttgart.

Beaton, R., 2005, 'Isaiah in Matthew's Gospel', in S. Moyise \& M.J.J. Menken (eds.) Isaiah in the New Testament, pp. 63-78, Clark, London. (The New Testament and the Scriptures of Israel).

Brock, S.P., 1977, 'Vol. 1: The Syriac versions', in B.M. Metzger (ed.), The early version of the New Testament: Their origin, transmission, and limitations, pp. 3-98, Clarendon, Oxford.
Brock, S.P., 1987, Isaiah, Brill, Leiden. (The Old Testament in Syriac according to the Peshitta version, 3,1 ).

Brock, S.P., 1992, 'Syriac versions', Anchor Yale Bible Dictionary, 6, 794-799.

Elliger, K. \& Rudolph, W., 1984, Biblia Hebraica Stuttgartensia, Deutsche Bibelgesellschaft, Stuttgart.

Gelston, A., 1980, Dodekapropheton, Brill, Leiden. (The Old Testament in Syriac according to the Peshitța version, 3, 4).

Hagner, D.A., 1998, Matthew 1-13, Word, Dallas. (Word Biblical Commentary, 33A).

Joosten, J., 1990, 'The Old Testament quotations in the Old Syriac and Peshitta Gospels: A contribution to the study of the Diatessaron', Hebrew Union College Annual 15, 55-76. http://dx.doi.org/10.2307/3267905

Joosten, J., 1996. The Syriac language of the Peshitta and Old Syriac versions of Matthew: Syntactic structure, inner-Syriac developments and translation technique, Brill, Leiden. (Studies in Semitic Languages and Linguistics).

Joosten, J., 2001, 'Tatian's Diatessaron and the Old Testament Peshitta', Journal of Biblical Literature 120(3), 501-523.

Kiraz, G.A., 1996, Comparative edition of the Syriac Gospels aligning the Sinaiticus, Curetonianus: Peshittâ and Harclean versions, vol. 1: Matthew, Brill, Leiden. (New Testament Tools and Studies, 21(1)).

Knowles, M.P., 2006, 'Scripture, history, Messiah: Scriptural fulfilment and the fullness of time in Matthew's Gospel', in S.E. Porter (ed.), Hearing the Old Testament in the New Testament, pp. 59-82, Eerdmans, Grand Rapids.

Menken, M.J.J., 2000, 'The quotation from Jeremiah 31(38).15 in Matthew 2:18: A study of Matthew's scriptural text', in S. Moyise (ed.), The Old Testament in the New: Essays in honour of J.L. North, Sheffield Academic Press, Sheffield. (Journal for the study of the New Testament supplement series, 189).

Menken, M.J.J., 2004, Matthew's Bible: The Old Testament text of the evangelist Peeters, Leuven. (Bibliotheca ephemeridum theologicum Lovaniensium, 173).

Moyise, S., 2001, The Old Testament in the New: An introduction, Continuum, London.

Rahlfs, A., 1979, Psalmi cum Odis, 3. Aufl., Vandenhoeck \& Ruprecht, Göttingen (Septuaginta Vetus Testamentum Graecum 10).

Shedinger, R., 1999, 'Did Tatian use the Old Testament Peshitta? A response to Jan Joosten', Novum Testamentum 41, 265-279. http://dx.doi.org/10.1163/ 156853699323281298

Walter, D.M., 1980, Psalms, Brill, Leiden. (The Old Testament in Syriac according to the Peshitta version. 2, 3)

Wildberger, H., 1991, Isaiah 1-12, Fortress, Minneapolis. (Continental commentary series).

Ziegler, J., 1967a, Duodecim prophetae, 2. Aufl., Vandenhoeck \& Ruprecht, Göttingen (Septuaginta Vetus Testamentum Graecum 13)

Ziegler, J., 1967b, Isaias, Vandenhoeck \& Ruprecht, Göttingen. (Septuaginta Vetus Testamentum Graecum 14).

Ziegler, J, 1976, Jeremias, Baruch, Threni, Epistula Jeremiae, 2. Aufl, Vandenhoeck \& Ruprecht, Göttingen. (Septuaginta Vetus Testamentum Graecum 15). 